\title{
Communicating Synthetic Biology: from the lab via the media to the broader public
}

\author{
Nicole Kronberger $\cdot$ Peter Holtz $\cdot$ Wolfgang Kerbe $\cdot$ \\ Ewald Strasser $\cdot$ Wolfgang Wagner
}

Received: 30 April 2009/Revised: 18 June 2009/Accepted: 29 June 2009

(C) The Author(s) 2009. This article is published with open access at Springerlink.com

\begin{abstract}
We present insights from a study on communicating Synthetic Biology conducted in 2008. Scientists were invited to write press releases on their work; the resulting texts were passed on to four journalists from major Austrian newspapers and magazines. The journalists in turn wrote articles that were used as stimulus material for eight group discussions with select members of the Austrian public. The results show that, from the lab via the media to the general public, communication is characterized by two important tendencies: first, communication becomes increasingly focused on concrete applications of Synthetic Biology; and second, biotechnology represents an important benchmark against which Synthetic Biology is being evaluated.
\end{abstract}

Keywords Public perceptions of Synthetic Biology · Communication $\cdot$ Anchoring

\section{Communicating Synthetic Biology in the public sphere}

More than 10 years have passed since both the imports of genetically manipulated crops and Dolly the Sheep led to public and NGO protests in Europe. Since then, whenever a new technology appears, the question arises whether the

\section{N. Kronberger $(\square)$}

London School of Economics and Political Science,

Houghton Street, London WC2A2AE, UK

e-mail: N.Kronberger1@1se.ac.uk; Nicole.Kronberger@jku.at

N. Kronberger · P. Holtz · W. Kerbe - E. Strasser · W. Wagner

Johannes Kepler University, Linz, Austria

W. Wagner

University of the Basque Country, San Sebastián, Spain new technology will be met with similar public reaction. Synthetic Biology (SB) receives considerable attention within expert circles, but the field is not yet prominent in the public domain. Media reporting has increased over the past few years (Cserer and Seiringer, in preparation) but the notion of "synthetic biology" has hardly entered public awareness. Very first studies on public perceptions of SB indicate that most lay people in the US say they have heard very little or nothing at all about SB [89\% in the representative study by Hart Research Associates (2008), and $82 \%$ in the online-survey by Kahan et al. (2009)]. We are not aware of similar studies in other parts of the world.

The fact that there has been little discussion about SB up to now does not mean, however, that it is uncontroversial. The first indication of an emerging public debate was an open letter to the Second International Conference on Synthetic Biology (SB 2.0) in May 2006, signed by 35 international NGOs, calling for inclusive public debate, regulation and oversight of the rapidly advancing field. The scientific community has tried to address the concerns by establishing self-imposed guidelines (Service 2006), with reference to the approach chosen for genetic engineering in the 1975 Asilomar declaration. In their analysis of the SYNBIOSAFE e-conference on the societal aspects of SB, Schmidt et al. (2008) highlight that within the SB community there is both a fear that public perceptions of SB might reignite past debates on genetic engineering and a hope that SB might be perceived as an emerging technology similar to nanotechnology, which is a technology that retained a comparatively more positive public image, at least in Europe [Gaskell et al. 2006; for an international comparison see Scheufele et al. (2008)].

The fact that the terminology and meaning of SB are widely unknown and free from "stigma" in the public domain (Kunreuther and Slovic 2001) makes SB an 
interesting technology to investigate in terms of sensemaking processes. Research has shown that evaluations of new phenomena are influenced by prior experiences with phenomena deemed similar (Slovic 1987): experiences with nuclear energy, with BSE or organic food, for example, provided a basis for lay people's evaluation of biotechnology. Similarly, the public's experiences with biotechnology or nanotechnology may represent a basis for evaluating SB. The concern here is with perceived similarities rather than with similarity in a scientific sense. In novel, rapidly changing contexts, people certainly do not need to know scientific details but they do need to form opinions; the 'pragmatic imperative' of everyday life demands evaluation even when important details are not known (Wagner and Hayes 2005; Wagner 2007). That is, in contrast to scientific observation, everyday life is not driven by epistemic goals but rather is characterized by the desire to know whether or not the novel requires further attention and action. There are two major networks through which information about technology-related events and evaluations flow: the news media and more informal personal networks, with different "amplification stations" - scientists, the media, groups of the public-joining in at different points in the communication process (Kasperson et al. 1988). The metaphor of amplification highlights that information is not passed on in an uninterested or unchanged way, but rather, individuals and groups re-construct the issue at hand from their own point of view. Thereby, both the hopes and the risks associated with a technology are either amplified or attenuated, depending on the perspective taken. Moving from the lab to public views, the interpretation of technologies will tend to be integrated into larger frames of values and the political agenda of social and political groups.

In the following we provide first insights on public views of SB in Europe, where public resistance to biotechnology has been considerably stronger than in the US (Gaskell et al. 2000). The research took place in Austria, a country with a relatively skeptic stance on biotechnology from the outset (Torgersen et al. 2001). Our analysis is based on a realworld experiment conducted in 2008. Scientists working in the field of SB were invited to write press releases on their work, which were passed onto Austrian journalists to be turned into newspaper articles that finally were presented to different groups of the public. In the following we ask: What makes scientific messages more or less likely to reach the public audiences? And what role does prior experience with biotechnology play in understanding and evaluating SB?

\section{Method}

In the following sections we describe the research design used for investigating the transformation of information on
$\mathrm{SB}$, as it was passed on from scientists to journalists and to some groups of the public.

Luring Synthetic Biology out of the lab

In order to cover the field of SB in a systematic way, subfields of SB were distinguished ${ }^{1}$ and 15 scientists representing these fields were invited to write a press release on their recent work. Five scientists, covering the fields of metabolic engineering, minimal organisms, and in silico research, participated in the study. Furthermore, two recently published press releases were included as this material perfectly coincided with the timing and the purpose of the study, and allowed for a more comprehensive representation of SB. These latter texts were released by the J. Craig Venter Institute (Scientists Create First Synthetic Bacterial Genome $)^{2}$ and by the Institute for OneWorld Health, Amyris Biotechnologies, and Sanofi Aventis (Agreement on the development of half-synthetic Artemisinin). ${ }^{3}$ In total seven press releases covering the most important developments in the field were available for the next step. ${ }^{4}$

\section{Making Synthetic Biology a newspaper headline}

The second part of our research design consisted of encouraging journalists to report on SB. Austrian science and health journalists were identified with the help of a journalists' database. An invitation was sent to 28 journalists working for daily newspapers and magazines, including high quality papers and tabloids, to write an article in a way that was ready for press.

Four journalists affiliated with the Austrian newspapers Der Standard, Salzburger Nachrichten, Österreich, and News, agreed to participate in the study. While three of these are daily newspapers, the latter is a weekly magazine. The journalists received the seven press releases as input for their article on SB. Upon receipt of the articles, they

\footnotetext{
1 The classification was based on Benner and Sismour (2005), O'Malley et al. (2008), and Schmidt (2009), and conducted with kind support from colleagues in the SYNBIOSAFE project (http://www. synbiosafe.eu/).

${ }^{2}$ http://www.jcvi.org/cms/research/projects/synthetic-bacterial-genome/ press-release/.

3 http://www.sanofi-aventis.de/live/de/medias/14315FF2-5B7B-4B8B9295-39DE4165E15D.pdf.

${ }^{4}$ Today many universities have media relations departments that edit press releases before publication. We acknowledge that our data consists both of edited and non-edited materials. It remains an open question to what degree this has influenced our results. However, we think that investigating reactions to non-edited releases produced by scientists themselves allow for interesting insights, especially since scientists will not always get reviewed before going public (e.g. when being interviewed, or speaking on the radio or TV).
} 
were asked to fill out a questionnaire that addressed aspects of reporting on SB. Finally, they participated in a telephone interview. The journalists were reimbursed for their participation in the study.

In line with the style of the editorial houses, the weekly magazine article contains considerably more words than the daily newspaper reports; furthermore, the more a daily newspaper is considered high quality press in Austria the longer the article is (Standard: 705 words, Salzburger Nachrichten: 353 words, Österreich: 286 words, News: 1,009 words).

Synthetic Biology meeting groups of the public

Finally, the newspaper articles were presented to eight groups of the lay public in September/October 2008. In order to ensure a realistic appearance, the articles were completed with logos and headers from the newspapers for which the journalists had supposedly produced the text.

For each group discussion 6-9 individuals were invited, with a total of 49 Austrian lay persons participating in the meetings. The criterion for group composition was maximisation of perspectives (Strauss and Corbin 1990). This means that selected groups were expected to be either positive (e.g. based on economic or scientific interests) or sceptical (e.g. based on religious or environmental grounds) about the topic. ${ }^{5}$ Furthermore, group composition was based on the criteria of sex, age, level of education, rural versus urban living area, and political views. For this analysis we focus on commonalities shared by the groups rather than on group differences, hence a more detailed description of the groups is irrelevant here.

Upon arrival, participants were welcomed and introduced to the topic of SB (beforehand, they were told that the discussion would be on "new technologies"). After making free associations with the term, participants were provided with copies of the four media articles. After a reading period of 10-15 minutes, the researchers encouraged a discussion on SB within the group. Finally, participants filled out a questionnaire, were debriefed and received financial compensation for travel and time expenditure. ${ }^{6}$ The discussions were tape-recorded and transcribed verbatim. These transcripts, together with the press releases and the media articles, represent the data used for the analyses reported in the following sections.

\footnotetext{
5 The following groups were selected because they could be expected to be partisan in some way: students of different disciplines; members of NGOs: either thematically related to the life sciences like Greenpeace or not thematically related like Amnesty International; individuals working for an economic interest institution or in a religious organisation.

${ }^{6}$ The Greenpeace Group did not accept this allowance on the ground of their strict anti-corruption policy.
}

\section{Results}

From lab to headline: application matters

In this section we ask what makes press releases more or less interesting for journalists reporting on SB. As discussed above, seven press releases were given to four journalists who in turn wrote a newspaper article on $\mathrm{SB}^{7}$ Two of the journalists indicated that they were familiar with Synthetic Biology; two said they were not. Both the press release headings and the news article headlines are shown in Table 1.

The journalists were asked to rank order the press releases according to their usefulness $(1=$ most useful, $7=$ least useful). Do the press releases differ in the journalists' evaluation? A Friedman test indicates that indeed they do; the null hypothesis that there is no difference between the press releases' usefulness can be rejected $\left(\chi^{2}=16.71, \mathrm{df}=6, p<0.05\right)$. Table 1 presents the press releases sorted by their mean rank. The journalists agree to a considerable degree which press releases are useful; But what features of the press releases make them more or less useful?

A closer look at Table 1 reveals that an important commonality of the press releases considered most useful by the journalists is that they discuss specific applications of SB (Artemisinin production, fuel production, detecting explosives). Similarly, in the news headlines, none refer explicitly to Synthetic Biology, but two of the four stress (medical) applications. Within the texts, all four articles discuss fuel production, three mention medical applications, and two the possibility of using SB for detecting explosives. Undoubtedly, the applications of SB play a key role in newspaper articles. In support of this finding, the journalists explicitly stressed that application matters. "The big question is: What are the benefits of the research result?", one journalist states. As such, press releases are noteworthy only when they are both new and closely related to the readers' problems and concerns.

With the exception of the press release from the Venter Institute, press releases considered most useful by the journalists also tended to contain relatively little "gene" vocabulary (words like gene, genetic, genome, genotype, DNA). Gene vocabulary can be considered an indicator of scientific description. Three of the four journalists indicated that besides the applicability of research findings, clarity and comprehensibility of the press releases are important criteria for selection. Good press releases are

\footnotetext{
${ }^{7}$ All four journalists, in addition to the press releases, indicated having looked for further information on the internet; three of the four journalists made use of other newspaper articles and one journalist indicated having read scientific journal articles.
} 
Table 1 Characteristics and reception of press releases

\begin{tabular}{|c|c|c|c|c|c|c|}
\hline & \multirow{2}{*}{$\begin{array}{l}\text { Mean } \\
\operatorname{rank}^{\mathrm{a}}\end{array}$} & \multirow{2}{*}{$\begin{array}{l}\text { Frequency gen* } \\
\text { words (total words) }\end{array}$} & \multicolumn{3}{|c|}{ Reference to application(s) } & \multirow{2}{*}{$\begin{array}{l}\text { Reference to risks } \\
\text { or moral aspects }\end{array}$} \\
\hline & & & Fuel & Medicine & Detection of explosives & \\
\hline \multicolumn{7}{|l|}{ Press releases } \\
\hline $\begin{array}{l}\text { Agreement on the development of } \\
\text { half-synthetic Artemisinin }^{\text {b }}\end{array}$ & 2.00 & $1(1283)$ & $\mathrm{x}$ & $\mathrm{X}$ & 0 & 0 \\
\hline $\begin{array}{l}\text { Scientists a step closer to producing fuel } \\
\text { from bacteria }\end{array}$ & 2.75 & $0(414)$ & $\mathrm{X}$ & 0 & 0 & 0 \\
\hline Synthetic bacterial genome & 2.75 & $54(1587)$ & $\mathrm{x}$ & 0 & 0 & $\boldsymbol{V}$ \\
\hline $\begin{array}{l}\text { First environmental applications of Synthetic } \\
\text { Biology }\end{array}$ & 3.50 & $2(453)$ & 0 & 0 & $\mathrm{X}$ & 0 \\
\hline $\begin{array}{l}\text { Bacterial genomes rules for the construction } \\
\text { of synthetic cells }\end{array}$ & 4.25 & $34(718)$ & 0 & 0 & 0 & 0 \\
\hline Living in symbiosis: just together? & 5.75 & $20(595)$ & 0 & $\mathrm{x}$ & 0 & 0 \\
\hline In silico cells the study evolution [sic] & 7.00 & 7 (312) & 0 & 0 & 0 & 0 \\
\hline \multicolumn{7}{|l|}{ Newspaper articles } \\
\hline Artificial life from the lab & & & $X$ & 0 & $X$ & $\checkmark$ \\
\hline Artificial life from the bio-designer & & & $X$ & $X$ & $X$ & $\checkmark$ \\
\hline Improved weapons against malaria & & & $\mathrm{x}$ & $X$ & 0 & 0 \\
\hline Bacteria for medicine & & & $X$ & $X$ & 0 & $\checkmark$ \\
\hline \multicolumn{7}{|l|}{ Group discussions } \\
\hline Group 1 & & & $\mathrm{X}$ & $\mathrm{X}$ & $\mathrm{X}$ & $\boldsymbol{V}$ \\
\hline Group 2 & & & $X$ & $X$ & $X$ & $\boldsymbol{\sim}$ \\
\hline Group 3 & & & $X$ & $\mathrm{X}$ & $X$ & $\checkmark$ \\
\hline Group 4 & & & $X$ & $\mathrm{X}$ & $X$ & $\checkmark$ \\
\hline Group 5 & & & $X$ & $X$ & $X$ & $\checkmark$ \\
\hline Group 6 & & & $X$ & $X$ & 0 & $\checkmark$ \\
\hline Group 7 & & & $X$ & $X$ & $X$ & $\checkmark$ \\
\hline Group 8 & & & $X$ & $X$ & $X$ & $\checkmark$ \\
\hline
\end{tabular}

$X$ Focus on specific application; $x$ parenthetic mentioning of application

${ }^{a}$ Press releases ranked according to usefulness as rated by journalists $(1=$ best, 7 = worst $)$

b Subtitle: Striving for a better provision of malaria patients

c Subtitle: Bacteria that detect explosives buried in soil

"prepared in a way that they are understandable for lay people", one journalist says, "this saves journalists painful work of translation; translation, which also increases the danger of errors ... The topic needs to be interesting for a broad readership, newspapers no longer can afford to publish specialised knowledge for specialists". If scientific terminology is being used, journalists want explanations and background information.

The two features of press releases deemed useful, that is application focus and relative frequency of gene talk (frequency of gene words/total words), are not unrelated. The press releases that focus on a specific application of SB make use of less gene talk $(\mathrm{M}=0.002, \mathrm{SD}=0.002$, $\mathrm{N}=3$ ) than those that do not focus on a specific application $(\mathrm{M}=0.034, \quad \mathrm{SD}=0.010, \quad \mathrm{~N}=4 ; \mathrm{F}=28.27$, $P<0.01)$. In this study, scientists who focus less on the scientific details but on implications of their research are more likely to be heard by the journalists.

One press release, namely the one released by the J. Craig Venter Institute, seems to represent an exception to what has been described so far: although the press release does not focus on a specific application of SB and contains a comparatively high proportion of gene vocabulary, it is nevertheless considered useful by the journalists. This press release, however, had been discussed extensively in the media at the beginning of 2008, so that it is likely that the journalists were already familiar with it. This press release is also unique in that it is the only press release that mentions the issues of (potential) risks and ethical aspects (by stating that the work of the group is under constant ethical review). No other press release mentions such issues. In contrast, three of the four newspaper articles take 
up the issue of possible risks, dangers or moral/ethical problems, but these issues are given relatively little space. ${ }^{8}$ Generally, the consideration of these issues does not go beyond the appraisal that risks and ethical aspects of SB need to be discussed.

Moving on from the media to the discussion groups, Table 1 suggests that the journalists' emphasis on application matches the concerns of the groups. All groups discussed all applications (fuel, medicine, detection of explosives), with the exception of the explosives detection not being discussed in the students' group. Moving from the lab to the public domain, SB is increasingly thought of in terms of its specific applications. Furthermore, the issue of risks and moral/ethical aspects were discussed in all groups, even if mostly in very general and vague terms. For the groups, SB is above all a new technology that promises both new opportunities and problems. But how do group discussants come to discuss risks and dangers when these issues are virtually absent in the press releases and parenthetically mentioned in the newspaper articles? This question is addressed in the next section.

Making sense of Synthetic Biology: old wine in new bottles?

While for scientists the ways SB relates to biotechnology might be irrelevant, it is important for the public. Anchoring is the process of classifying, categorizing and naming the new and unknown (Moscovici 2001). By seeing the unfamiliar in the light of a more familiar technology, the unfamiliar is linked to a multitude of references, taking a more familiar and meaningful form. In everyday life, people need not understand scientific details, but rather how to act with regard to the unfamiliar. "What does the new technology mean for us?", is the question. Hence, anchoring SB in biotechnology might be a lay strategy to make sense of the innovation. If SB is anchored in terms of biotechnology, then former controversies on biotechnology will be relevant for SB as well. In the following we investigate whether, and in what ways, SB is linked to or contrasted with biotechnology in the scientific press releases, in the news articles, and in the peer-to-peer discussions.

Table 2 shows both the frequencies of gene vocabulary (such as gene, genome, genetic, DNA, etc.) and the frequencies of biotech vocabulary (such as genetic engineering, genetic manipulation, genetic modification, biotechnology, cloning, Dolly) for all three types of communication. Although the two types of vocabulary certainly

\footnotetext{
8 A media analysis on SB from 2004 onwards in Austrian, German and Swiss print media shows that in most of the published news articles, potential benefits were mentioned, but only half or less of them referred to potential risks and/or ethical aspects (Cserer and Seiringer, in preparation).
}

are related, in this context, contrasting them allows for interesting insights. Thus, the gene vocabulary is considered as a proxy for scientific description and detail, while the biotech vocabulary is understood as a proxy for the degree of anchoring of SB in former debates on biotechnology. Proportions of gene versus biotech words within each type of text highlights that along the communication process the proportions change considerably. While in the press releases the proportion of gene to biotech vocabulary is 17 to 1 , it is 2 to 1 in the media reporting, and reverses in the group discussions to a proportion of 1 to 3 . This means that overall, the discussion moves away from the concrete processes and findings of SB to a broader discussion that is clearly anchored in a discussion of biotechnology. But what does this mean? Is this good or bad news for SB? In the following we take a more in-depth look at the different stations in the communication process.

\section{Scientists}

The scientists writing the press releases clearly avoid linking their work to biotechnology. Only once is SB explicitly related to genetic engineering: "A major goal of $\mathrm{SB}$ is to understand which pathways of the bacterial metabolism are responsible for important functions, and then genetically engineer organisms that can perform the desired function more effectively". A few other references address biotechnology as (unsuccessful) development of the past, or include implicit references to biotechnology (e.g. by naming laboratories, companies, or journal titles).

\section{Media reporting}

These tendencies are mirrored in news reporting. On the one hand, there are references to past biotech

Table 2 Proportion of gen* words and biotech* words within the press releases, media articles and group discussions

\begin{tabular}{lll}
\hline & Gen* words & Biotech* words \\
\hline $\begin{array}{ll}\text { Press releases }(\mathrm{N}=7) \\
\text { Minimum/maximum }\end{array}$ & $0 / 54$ & $0 / 5$ \\
Mean & 16.86 & 1.43 \\
$\mathrm{SD}$ & 20.56 & 2.15 \\
Media articles $(\mathrm{N}=4)$ & & \\
Minimum/maximum & $1 / 14$ & $1 / 5$ \\
Mean & 4.75 & 3.00 \\
SD & 6.18 & 1.83 \\
Group discussions $(\mathrm{N}=8)$ & & \\
Minimum/maximum & $4 / 19$ & $15 / 86$ \\
Mean & 10.13 & 32.00 \\
SD & 5.11 & 23.01 \\
\hline
\end{tabular}


developments. However, the increase in biotech vocabulary primarily stems from the fact that those "doing" SB must be named: frequently they are called genetic engineers or biotechnologists. ${ }^{9}$ In contrast to the press releases, there also are a few instances in the news articles relating SB to biotechnology in terms of regulation, risks and ethical issues: "Critics point out that there still are no laws and regulations although Synthetic Biology goes far beyond traditional genetic engineering procedures" or "The controversies on nuclear energy and on genetically modified plants and stem cells have shown how important an early debate on safety issues and ethical aspects is".

\section{Group discussions}

In the group discussions, references to biotechnology and genetic engineering are frequent and varied. ${ }^{10}$ Having been confronted with the notion of "synthetic biology" at the beginning of the discussions, all of the groups reported being unfamiliar with the topic. However, after having read the newspaper articles, a number of respondents reported feeling vaguely familiar with what SB is about. As such, SB often is interpreted as either a part, or as a further development of biotechnology. Part of the increase in biotech vocabulary therefore is due to the fact that the question of whether SB is biotechnology or not is ardently debated. ${ }^{11}$ Repeatedly, the groups concluded that SB is the "next step" or "logical continuation" of genetic engineering. Furthermore, an increase in biotech vocabulary represented a rapid move away from definitions of SB to a broader evaluation of the development. SB is indeed perceived to be very similar to biotechnology: it is seen as raising comparable questions; to imply interfering with nature, life and the eco-system; and consequently as posing similar moral questions and risks (such as side effects spiraling out of control or unpredictable long-term consequences). Furthermore, SB is being associated with biotechnology (and other technologies) in a more general way. The groups emphasize that SB, like biotechnology, can be used for good and bad; it is about comparable goals (e.g. for medical, environmental or energy applications); it might well be driven by potent companies investing big

\footnotetext{
9 Sometimes they are also called "bio-engineers", "bio-designers", and the like.

${ }^{10}$ It was made sure that the biotechnology aspect was not introduced by the interviewer and only taken up if introduced by the group itself.

${ }^{11}$ Most groups came to the understanding that while genetic engineering means changing, SB implies creating or manufacturing life from scratch. While some see this to be a critical and dangerous development, others think that-as long as applied to bacteria (and not to more developed beings such as animals or human beings) constructing what already exists in nature is not particularly worrisome.
}

money; and it is expected to be hard to control in terms of (international) political decision-making and regulation. In summary, the hopes and concerns about SB correspond highly with the concerns voiced in different European countries about biotechnology some years ago (Wagner et al. 2001). Even the engineering aspect of SB, which was expected to raise concerns (Schmidt 2006), meets relatively little discussion among the public: with notions like "genetic engineering" or "biotechnology", and techniques such as cloning, everyday people already feel acquainted with the idea of an engineered approach to life. This does not mean that the issue does not raise concerns; however, it does not raise more or less concerns than biotechnology has in the past and present.

In a nutshell, one might argue, science has arrived at a stage, which catches up with public fantasies that came to the fore in the context of biotechnology in the 1990s. Now it is possible to do what the public imagined was already possible years ago. As such, SB appears to be old wine in new bottles. ${ }^{12}$

At the end of the discussions, respondents were asked in a questionnaire whether they think that SB will deteriorate, have no effect, or improve our way of life over the next years. Forty-four percent of our discussants say that they do not know; $16 \%$ think that SB will deteriorate life; $10 \%$ believe that it will have no effect; and 30\% say that SB will improve life. Many participants in our study feel insecure about what to expect from the new technology. One might conclude that in terms of public evaluation, the fate of SB still is an open question. There are people who are sceptical and who might mobilise to take action against SB. Other groups feel confident that overall the innovation will turn out to be beneficial, while others still are hesitant to take sides. This latter uncertainty may be surprising, that is, if $\mathrm{SB}$ is indeed anchored in biotechnology. But SB, like biotechnology, might not be a uniform development and lead to a variety of applications. The history of biotechnology has shown that while GM food was met with high levels of opposition, biotechnology in the medical domain experienced much more support (Gaskell et al. 2006). The

\footnotetext{
12 If SB so clearly is understood in terms of biotechnology, might it not be the case that it is also compared to nanotechnology which, at least in Europe, is typically evaluated in a more positive light? In our data, nanotechnology was mentioned only in two groups, namely in those groups with the most advanced understanding of SB: the Greenpeace group and the student group. In the student group, one participant mentioned nanotechnology at the beginning of the discussion when speculating what SB might be about. In the Greenpeace group, a participant recalled reading an article on nanotechnology, highlighting the merging tendencies of engineering and biology. Still, in both groups, the issue of nanotechnology was not taken up by other members nor was it discussed further. Nanotechnology is therefore clearly not an anchor for making sense of SB.
} 
different applications of nanotechnology also seem to be met with varying levels of support (Pidgeon et al. 2008). Similarly, people might also await SB's different applications, while remaining alert to its potential problems and risks.

\section{Conclusion}

SB can be seen as an innovation that challenges the takenfor-granted and that needs to be 'symbolically coped with' by social actors (Wagner et al. 2002). SB still seems to be in the pre-coping phase, a phase characterized by low levels of public knowledge and uncertainty on what to think about the new technology. Different groups take up aspects of the innovation and combine it with former experiences and knowledge. Biotechnology represents an important anchor for sense-making of SB in the public domain. While in our study neither journalists nor group discussants are sure about whether SB should be considered part of biotechnology or not, they agree that both technologies pose similar questions, opportunities and problems. It is therefore not surprising that SB is considered newsworthy by journalists only if it results in (or at least promises) useful applications; as with biotechnology, perceived usefulness might turn out to be crucial for the development (Gaskell et al. 2001; see also Gaskell et al. 2004). In our field experiment, the fact that SB deals with the understanding and construction of life, in itself, is not perceived as different enough from biotechnology to merit special attention. Anchored in biotechnology, SB is not met with much surprise-it seems to be generally interpreted as old wine in new bottles. Whether and to what degree this result holds in other countries is an open question, and further research is needed. However, if SB is so clearly anchored in biotechnology in Austria, it is likely that it will be so in other countries as well. Solely depicting SB rhetorically as different from biotechnology, hence will not be enough to ensure public support. Everyday people, at least in our study, clearly link SB to biotechnology and its history, and want important questions to be addressed: What are the claimed benefits? And what is done to deal with risks and moral problems? How can SB be controlled?

Acknowledgements This research was funded by the Austrian Ministry of Science programme GenAU (COSY: Communicating Synthetic Biology; GZ BMWF-200.184/0001-II/1a/2008). The first author furthermore received financial support within the seventh Framework People Program of the European Commission (PIEF-GA2008-220999). We are grateful to Amélie Cserer, Sandra Doblhammer, Ulrich Fiedeler, Brigitte Gschmeidler, Markus Schmidt, Alexandra Seiringer and Helge Torgersen for support in conducting the research. Furthermore, we appreciate their and two anonymous reviewers' helpful comments on an earlier version of this article.
Open Access This article is distributed under the terms of the Creative Commons Attribution Noncommercial License which permits any noncommercial use, distribution, and reproduction in any medium, provided the original author(s) and source are credited.

\section{References}

Benner SA, Sismour AM (2005) Synthetic biology. Nat Rev Genet 6:533-543

Gaskell G, Allum N, Bauer M, Durant J, Allansdottir A, Bonfadelli H, Boy D, de Cheveigné S, Fjaestad B, Gutteling JM, Hampel J, Jelsoe E, Correia Jesuino J, Kohring M, Kronberger N, Midden C, Nielsen TH, Przestalski A, Rusanen T, Sakellaris G, Torgersen H, Twardowski T, Wagner W (2000) Biotechnology in the European public. Nat Biotechnol 18:935-938

Gaskell G, Allum N, Wagner W, Nielsen TH, Jelsoe E, Kohring M, Bauer M (2001) In the public eye: representations of biotechnology in Europe. In: Gaskell G, Bauer M (eds) Biotechnology 1996-2000. The years of controversy. Science Museum, London, pp 53-79

Gaskell G, Allum N, Wagner W, Kronberger N, Torgersen H, Hampel $\mathrm{J}$ et al (2004) GM foods and the misperception of risk perception. Risk Anal 24:185-194

Gaskell G, Allansdottir A, Allum N, Fischler C, Hampel J, Jackson J, Kronberger N, Mejlgaard N, Revuelta G, Schreiner C, Stares S, Torgersen H, Wagner W (2006) Europeans and biotechnology in 2005: patterns and trends. A report to the European Commission's Directorate General for Research. http://www.ec.europa. eu/research/press/2006/pr1906en.cfm. Accessed 30 Apr 2009

Hart Research Associates on behalf of the Project On Emerging Nanotechnologies at The Woodrow Wilson International Center For Scholars (2008) http://www.pewtrusts.org/uploadedFiles/ wwwpewtrustsorg/Reports/Nanotechnologies/final-synbioreport. pdf. Accessed 30 Apr 2009

Kahan DM, Braman D, Mandel GN (2009) Risk and culture: is synthetic biology different? Harvard Law School program on risk regulation research paper No. 09-2. SSRN: http://ssrn.com/ abstract $=1347165$. Accessed 30 Apr 2009

Kasperson RE, Renn O, Slovic P, Brown HS (1988) The social amplification of risk: a conceptual framework. Risk Anal 8:177187

Kunreuther H, Slovic P (2001) Coping with stigma. In: Flynn J, Slovic P, Kunreuther H (eds) Risk, media and stigma. Earthscan, London, pp 331-352

Moscovici S (2001) Social representations. Explorations in social psychology (Duveen G, ed). New York University Press, New York

O'Malley M, Powell A, Davies JF, Calvert J (2008) Knowledgemaking distinctions in synthetic biology. Bioessays 30:57-65

Pidgeon N, Herr Harthorn B, Bryant K, Rogers-Hayden T (2008) Deliberating the risks of nanotechnologies for energy and health applications in the United States and United Kingdom. Nat Nanotechnol 4:95-98

Scheufele DA, Corley EA, Shih T-J, Dalrymple KE, Ho SS (2008) Religious beliefs and public attitudes toward nanotechnology in Europe and the United States. Nat Nanotechnol 4:91-94

Schmidt M (2006) Public will fear biological accidents, not just attacks. Nature 441:1048

Schmidt M (2009) Do I understand what I can create? Biosafety issues in synthetic biology. In: Schmidt M, Kelle A, Ganguli A, de Vriend $\mathrm{H}$ (eds) Synthetic biology. The technoscience and its societal consequences. Springer Academic Publishing, New York 
Schmidt M, Torgersen H, Ganguli-Mitra A, Kelle A, Deplazes A, Biller-Andorno N (2008) SYNBIOSAFE e-conference: online community discussion on the societal aspects of synthetic biology. Syst Synth Biol 2:7-17

Service RF (2006) Synthetic biologists debate policing themselves. Science 312:1116

Slovic P (1987) Perception of risk. Science 236:280-285

Strauss A, Corbin J (1990) Basics of qualitative research. Grounded theory procedures and techniques. Sage, Newbury Park

Torgersen H, Egger C, Grabner P, Kronberger N, Seifert F, Weger P, Wagner W (2001) Austria: narrowing the gap with Europe. In: Gaskell G, Bauer M (eds) Biotechnology 1996-2000. The years of controversy. Science Museum, London, pp 131-144

Wagner W (2007) Vernacular science knowledge in everyday life: why would people want to know anything about science? Public Underst Sci 16:7-22
Wagner W, Hayes N (2005) Everyday discourse and common sense. The theory of social representations. Palgrave Macmillan, New York

Wagner W, Kronberger N, Gaskell G, Allansdottir A, Allum N, Cheveigné S (2001) Nature in disorder: the troubled public of biotechnology. In: Gaskell G, Bauer M et al (eds) Biotechnology 1996-2000. The years of controversy. Science Museum, London, pp 80-95

Wagner W, Kronberger N, Seifert F (2002) Collective symbolic coping with new technology: knowledge, images and public discourse. Br J Soc Psychol 41:323-343 